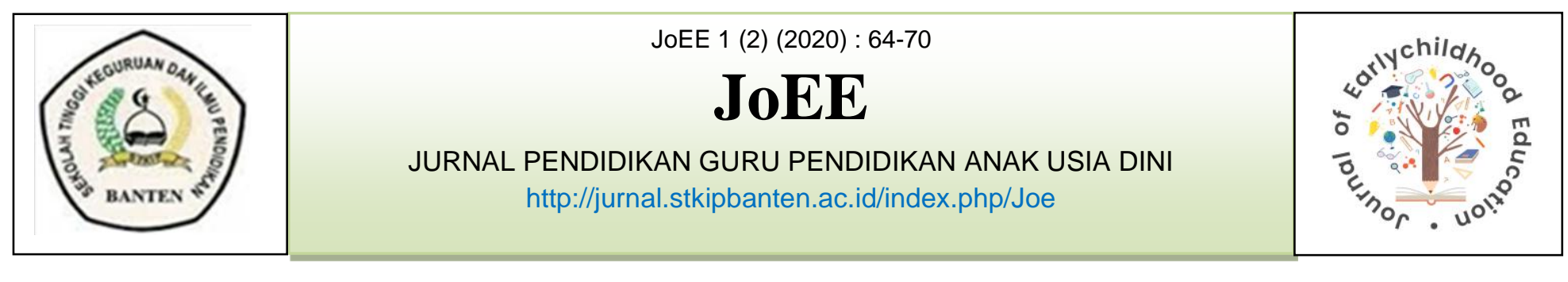

\title{
MENINGKATKAN KEMAMPUAN MENARI ANAK USIA DINI MELALUI KEGIATAN TARI KREASI "YAMKO RAMBE YAMKO" DI KELOMPOK B PAUD AN-NAZWA KECAMATAN CIKEUSAL
}

\author{
Larasati Nur Indah Prawesti \\ iiazzprawesti@gmail.com \\ Pendidikan Guru Pendidikan Anak Usia Dini \\ Sekolah Tinggi Keguruan dan Ilmu Pendidikan Banten
}

\begin{abstract}
ABSTRAK
Penelitian ini merupakan penelitian tindakan kelas yang dilakukan secara kolaborasi. Penelitian ini menggunakan desain PTK Kemmis dan Mc.Taggart yang dilakukan dengan menggunakan 2 siklus dan 2 kali pertemuan. Jika pada siklus ke 2 penelitian belum mencapai keberhasilan maka akan dilakukan penelitian lanutan pada siklus selanutnya. Masing-masing siklus terdiri dari 4 tahapan penyusunan rencana tindakan, pelaksanaan tindakan, observasi atau pengamatan dan refleksi. Subjek dalam penelitian ini adalah anak kelompok B. Jumlah anak yang diteliti sebanyak 15 anak. Lokasi penelitian dilaksanakan ditempat tugas peneliti yaitu PAUD An-Nazwa. Teknik pengumpulan data yang digunakan dalam penelitian ini adalah observasi dan dokumentasi. Alat-alat yang digunakan untuk mendapatkan data lengkap adalah pedoman observasi, arsip-arsip dan kamera foto. Analisis data dilakukan untuk mengolah dan menginterpretasi data dengan tujuan memperoleh informasi yang sesuai untuk tujuan penelitian. Analisis data yang menggunakan teknik deskriptif kualitatif digunakan untuk menentukan peningkatan proses belajar melalui tindakan yang diberikan. Pada penelitian ini triangulasi atau membandingkan dengan bantuan teman sejawat yang samasama melakukan penelitian, guru kolabolator dan dosen pembimbing sebagai pihak ahli dalam hal penelitian. Simpulan dari penelitian ini adalah terdapat peningkatan kemampuan menari anak usia dini di kelompok B PAUD An Nazwa dari siklus 1 sebesar 33\% naik menjadi 100\% pada siklus 2 dengan dengan jumlah anak 15 orang yang memiliki perkembangan Berkembang Sesuai Harapan dan Berkembang Sangat Baik. Persentase pada pertemuan 2 sudah mencapai keberhasilan maka keputusannya adalah penelitian dihentikan.. Keberhasilan penelitian ini didukung oleh peningkaan kemampuan guru dalam menerapkan metode demonstransi pada penerapan tindakan penelitian dengan nilai 100 di siklus 2 .
\end{abstract}

Kata Kunci :Tari Kreasi, Yamko Rambe Yamko, Motorik Kasar, Anak Usia Dini. 



\section{PENDAHULUAN}

\section{A. Latar Belakang}

Menari merupakan kegiatan yang dianggap dapat meningkatkan perkembangan motorik kasar anak. Temuan di lapangan menunjukkan bahwa kemampuan menari anak usia dini belum sesuai dengan harapan. Hal ini terlihat dari ketidakfokusan anak saat menari. Selain itu guru kurang dalam memberikan kegiatan menari kepada anak khususnya tari kreasi dari tarian tradisional. Pengenalan tari tradisional perlu dilakukan sejak dini sebagai bentuk pelestarian.

Menari tari kreasi tradisional dari daerah merupakan salah satu bentuk dalam memperkenalkan anak pada kesenian sejak dini. Tari Yamko Rambe Yamko merupakan tari yang penuh semangat hal ini sesuai dengan karakter anak usia dini yang semangat. Melalui menari, anak diharapkan dapat terangsang kemampuan motorik kasarnya. Selain itu melalui menari anak dapat memiliki wiraga, wirahma dan wirasa yang sesuai dengan harapan. Selain tiga aspek penting dalam menari anak berkembang, melalui tari anak akan mendapatkan menyalurkan bakatnya.

Berdasarkan pengamatan sebagai guru di PAUD An-Nazwa banyak hal yang menyebabkan anak memiliki kemampuan menari yang kurang sesuai dengan harapan. Kurangnya kegiatan menari yang dilakukan guru kepada anak usia dini, sebagai salah satu penyebabnya. Permasalahan lainnya adalah kurangnya kegiatan belajar motorik kasar yang menuntut anak untuk maju ke depan dalam melakukan kegiatan, karena sekolah lebih banyak melakukan kegiatan motorik halus. Kegiatan belajar cenderung monoton, sehingga membuat anak malas untuk bergerak. Kurangnya kemampuan motorik kasar anak karena media dan kegiatan yang disediakan guru kurang menarik, teknik serta metode yang diberikan guru kurang tepat.

\section{B. Rumusan Masalah}

Bertolak dari batasan masalah tersebut, dapat ditarik suatu rumusan masalah dalam penelitian yaitu apakah terdapat peningkatan kemampuan menari anak usia dini melalui kegiatan tari kreasi "Yamko Rambe Yamko" di kelompok B PAUD An-Nazwa Kecamatan Cikeusal?

\section{Tujuan Penelitian}

Penelitian ini memiliki tujuan yaitu mengetahui peningkatkan kemampuan menari anak usia dini melalui kegiatan tari kreasi "Yamko Rambe Yamko" di kelompok B PAUD An-Nazwa Kecamatan Cikeusal.

\section{LANDASAN TEORI}

Menurut Astuti tari dapat dimaknai sebagai ungkapan ekspresi sekaligus sebagai sarana komunikasi bagi seorang seniman kepada orang lain (2016 : 1). Selanjutnya Juliawati tari merupakan penggambaran jiwa yang diungkapkan melalui gerak yang indah $(2011: 8)$

Menurut Rachmawati dan Kurniati kecerdasan kinestetis tubuh merupakan keahlian individu dalam mengolah tubuhnya, mengekspresikan gagasan dan emosi melalui gerakan, termasuk di dalamnya kemampuan 
mengefektifkan gerakan dalam melakukan atau membuat sesuatu. Kegiatan kreatif dibidang ini di antaranya adalah tari (2012: 24)

Menurut Rabani berlatih tari memiliki tujuan mengasah kreatifitas anak dan kecintaan terhadap seni (2014 : 45). Menurut Mulyanai melalui pendidikan seni tari, anakanak diharapkan mampu mengungkapkan ide-ide, imajinasi dan fantasinya secara kreatif (2017 41-42).

Menurut Kurnia tari kreasi adalah karya tari garapan baru yang berunsur tradisi. Tarian ini tidak berpijak pada aturan yang telah ada. Para pencipta tari kreasi dituntut untuk kreatif, mengolaborasi, memodifikasi bahkan menciptakan variasi baru dalam seni tari tanpa meninggalkan jejak asli yang menjadi ciri khas (2016: 7).

Menurut Yus hasil belajar dimensi perkembangan fisik di antaranya yaitu berkembangnya kemampuan motorik kasar, koordinasi dan keseimbangan untuk melakukan berbagai gerak dan pada perkembangan seni hasil belajarnya yaitu anak dapat bergerak sesuai dengan irama musik (2015 : 30-31)

Menurut Mulyani dalam sebuah pembelajaran tari, anak belajar bagaimana bergerak, mempergunakan gerak, serta mengembangkan kemampuannya melalui gerak. Gerakan dasar dalam pembelajaran seni tari untuk anak usia dini, seperti berjalan, melompat, berputar, menggerakkan pergerakan tangan, kepala, dan kombinasi dari gerak tersebut sebagai rangsangan dalam perkembangan motorik khususnya motorik kasar karena gerakannya banyak menggunakan kemampuan mengontrol otot-otot besar (2016 : 90).

\section{METODE PENELITIAN}

\section{A. Metode Penelitian}

Penelitian ini merupakan penelitian tindakan kelas yang dilakukan secara kolaborasi. Penelitian ini menggunakan desain PTK Kemmis dan Mc.Taggart yang dilakukan dengan menggunakan 2 siklus dan 2 kali pertemuan. Jika pada siklus ke 2 penelitian belum mencapai keberhasilan maka akan dilakukan penelitian lanutan pada siklus selanutnya.

\section{B. Subjek dan Lokasi Penelitian}

Subjek dalam penelitian ini adalah anak kelompok B di PAUD An-Nazwa Kecamatan Cikeusal. Jumlah anak yang diteliti sebanyak 15 anak.

Lokasi penelitian

dilaksanakan ditempat tugas peneliti yaitu PAUD An-Nazwa Kecamatan Cikeusal Kabupaten Serang Provinsi Banten

\section{Teknik Pengumpulan Data}

Teknik pengumpulan data yang digunakan dalam penelitian ini adalah observasi dan dokumentasi. Alat-alat yang digunakan untuk mendapatkan data lengkap adalah pedoman observasi, arsip-arsip dan kamera foto.

\section{Teknik Analisis Data}

Analisis data dilakukan untuk mengolah dan menginterpretasi data dengan tujuan memperoleh informasi yang sesuai untuk tujuan penelitian. Analisis data yang menggunakan 
teknik deskriptif kualitatif digunakan untuk menentukan peningkatan proses belajar melalui tindakan yang diberikan dan merujuk pada data kualitas objek penelitian seperti Belum Berkembang, Mulai Berkembang, Berkembang Sesuai Harapan dan Berkembang Sangat Baik.

E. Teknik Pengujian Keabsahan Data Pada penelitian ini triangulasi atau membandingkan dengan bantuan teman sejawat yang sama-sama melakukan penelitian, guru kolabolator dan dosen pembimbing sebagai pihak ahli dalam hal penelitian.

\section{HASIL DAN PEMBAHASAN}

\section{A. Deskripsi Tempat dan Objek Penelitian}

Nama Lembaga KB. Cikeusal, Alamat J1. Raya Panosogan Kp. Cikeusal Lor RT 09/RW 02 Desa Cikeusal Kecamatan Cikeusal Kabupaten Serang.

Adapun hasil dari tindakan keberhasilan penelitian pada siklus 1 pertemuan 1 tidak menunjukkan keberhasilan penelitian, selanjutnya pada pertemuan 2 keberhasilan penelitian baru mencapai 33\% dengan jumlah anak 5 orang yang memiliki perkembangan Berkembang Sesuai Harapan. Persentase pada pertemuan 2 belum mencapai keberhasilan penelitian sehingga tindakan perlu dilakukan kembali di siklus selanjutnya.

\section{Diagram 4.1 Peningkatan Menari Anak Usia Dini}

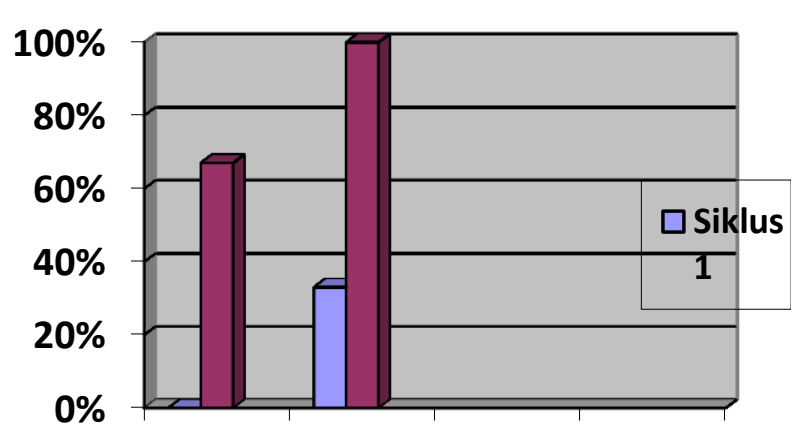

\section{Pertemulaerlemuan 2}

Adapun hasil dari tindakan keberhasilan penelitian pada siklus 2 pertemuan 1 tidak menunjukkan keberhasilan yang belum maksimal dari seluruh anak yang diteliti sudah mendapat nilai BSH dan BSB. Selanjutnya pada pertemuan 2 keberhasilan penelitian telah mencapai $100 \%$ dengan jumlah anak 15 orang yang memiliki perkembangan Berkembang Sesuai Harapan dan Berkembang Sangat Baik. Persentase pada pertemuan 2 sudah mencapai keberhasilan maka keputusannya adalah penelitian dihentikan.

\section{Diagram 4.2 Peningkatan \\ Kemampuan Guru dalam Mengajar Menari}

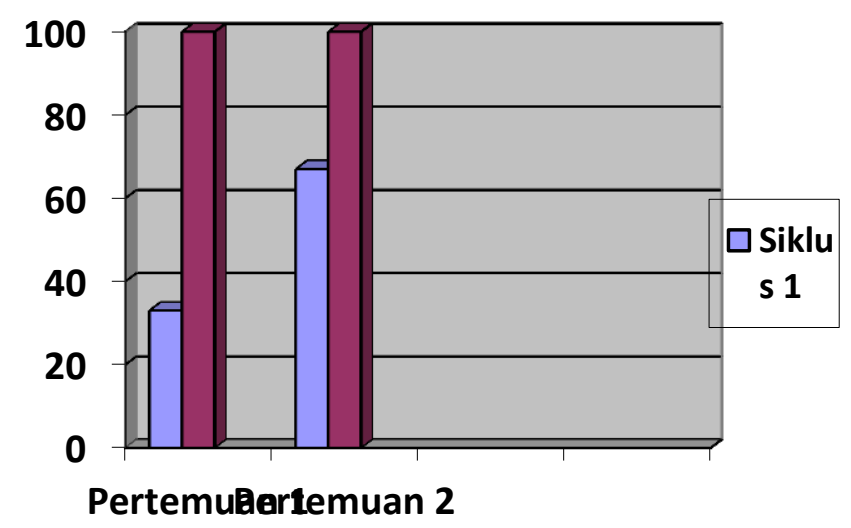


Peningkaan kemampuan menari anak usia di kelompok B PAUD An-Nazwa dari siklus 1 ke siklus 2 mengalami peningkatan persentase pada $80 \%$ - $100 \%$ sangat meningkat sebanyak 13 orang anak, $75 \%-79 \%$ meningkat sebanyak 2 orang anak. Persentase $70 \%-74 \%$ kriteria cukup meningkat dan $65 \%$ $69 \%$ kurang meningkat tidak diperoleh oleh anak.

Peningkatan persentase kemampuan menari anak tersebut didukung oleh keberhasilan penelitian pada siklus 2 sebesar 100\% sehingga penelitian dihentikan. Pendukung lainnya adalah kemampuan guru dalam menerapkan metode demonstrasi menari nilai kemampuan guru dalam menerapkan metode demonstradi pada siklus 2 pertemuan 1 dan 2 ialah bernilai 100, artinya guru mampu melakukan gerakan tari sehingga kemampuan menari anak ikut berkembang hingga pada perkembangan Berkembang Sesuai Harapan dan Berkembang Sangat Baik.

\section{Diagram 4.3 Pesentase}

\section{Peningkatan Kemampuan Menari} Anak Usia Dini

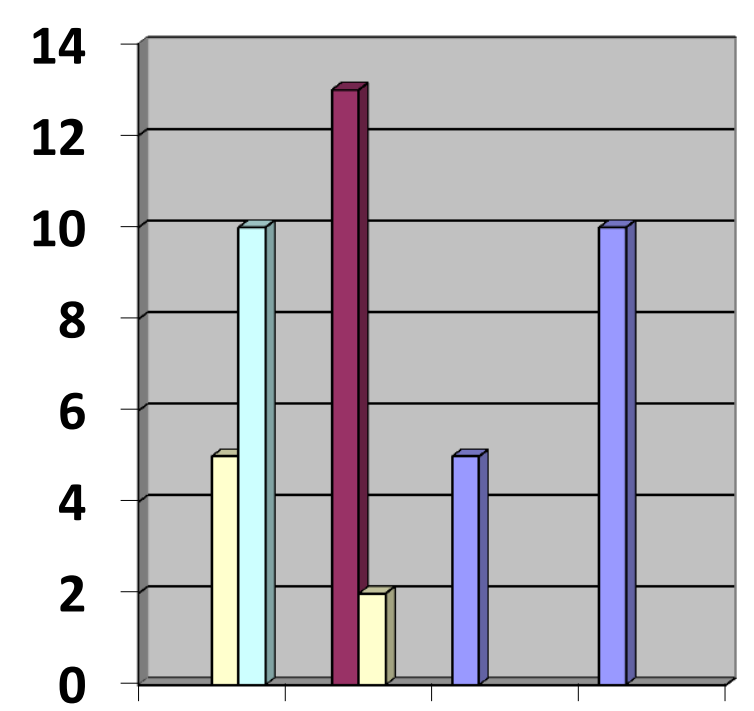

Siklus Siklus

12

\section{SIMPULAN}

Simpulan dari penelitian ini adalah terdapat peningkatan kemampuan menari anak usia dini di kelompok B PAUD An Nazwa dari siklus 1 sebesar $33 \%$ naik menjadi $100 \%$ pada siklus 2 dengan dengan jumlah anak 15 orang yang memiliki perkembangan Berkembang Sesuai Harapan dan Berkembang Sangat Baik. Persentase pada pertemuan 2 sudah mencapai keberhasilan maka keputusannya adalah penelitian dihentikan.. Keberhasilan penelitian ini didukung oleh peningkaan kemampuan guru dalam menerapkan metode demonstransi pada penerapan tindakan penelitian dengan nilai 100 di siklus 2 .

\section{DAFTAR PUSTAKA}

Decaprio, Richard. (2013). Aplikasi Teori Pembelajaran Motorik Di Sekolah. Yogyakarta: Diva Press. 
Dewi. Resi Septiani. (2012). Kenanekaragaman Seni Tari Nusantara. Jakarta : Balai Pustaka.

Didith Pramunditya Ambara. (2014). Asesmen Anak Usia Dini, Yogyakarta: Graha Ilmu.

Astuti. Fuji. (2016). Pengetahuan dan Teknik Menata Tari untuk AUD. Jakarta : Kencana.

Juliawati, Anita. (2011). Aneka Tari Bali. Jakarta Timur: CV. Ghina Walafafa.

Kunia, Muhdi. (2016). Tari Tradisi Melayu : Eksistensi dan Revitalisasi Seni. Medan : Puspantara.

Mulyani, Novi (2016). Pendidikan Seni Tari Anak Usia Dini. Yogyakarta: Penerbit Gava Media.

— (2017). Pengembangan Seni Anak Usia Dini. Bandung : Remaja Rosdakarya.

Rabani, Fikri. (2014). Petunjuk Pelaksanaan Sentra PAUD. Tanggerang : CV. Wahana Cipta Mandiri.

Rachamawati, Yeni dan Euis Kurniati.(2012). Strategi Pengembangan Kreativitas Pada Anak : Usia Taman Kanak-Kanak. Jakarta : Prenadamedia group.

Trianto. (2013). Desain Pembelajaran Tematik Bagi Anak Usia Dini TK/RA/Anak Usia Kelas Awal SD/MI. Jakarta : Prenadamedia Group.

Walujo, Adi dan Anies Listyowati. (2017). Kompendium PAUD :
Memahami PAUD Secara

Singkat. Jakarta :

Prenadamedia Group.

Yakub. Yenni. Patriani. (2010). Mengenal Tarian Tunggal Nusantara. Jakarta Timur: Horizon.

Yus, Anita. (2015). Penilaian Perkembangan Belajar Anak Taman Kanak-Kanak. Jakarta : PrenadaMedia Group. 